\title{
UPAYA PENINGKATAN MINAT DAN PRESTASI BELAJAR SISWA SMKN 3 KOTA JAMBI MELALUI MODEL PEMBELAJARAN KOOPERATIF TIPE GROUP INVESTIGATION
}

\author{
SUHUDI \\ SMK Negeri 3 Kota Jambi Provinsi Jambi \\ Email : suhudi66@gmail.com
}

\begin{abstract}
ABSTRAK
Penelitian ini bertujuan untuk meningkatkan minat dan prestasi belajar siswa Kelas XII TIPTL 2 SMK Negeri 3 Kota Jambi tahun pelajaran 2018/2019 dengan menggunakan Model Pembelajaran Kooperatif Tipe Group Investigation pada mata pelajaran Instalasi Motor Listri (IML). Metode penelitian ini adalah PTK (Penelitian Tindakan Kelas). Populasi penelitian menggunakan seluruh siswa kelas XII SMK Negeri 3 Kota Jambi dan subjek penelitian ini yaitu siswa kelas XII TIPTL 2 terdiri dari 23 siswa. Penelitian dilaksanakan dua siklus, dibantu oleh dua observer, pengumpulan data menggunakan tes dan pengamatan. Hasilnya menunjukkan peningkatan dengan menggunakan model ini. Hal ini ditunjukkan dengan adanya peningkatan persentase hasil rata-rata lembar angket minat belajar Teknik Instalasi Pemanfaatan Tenaga Listrik (TIPTL) setiap siklusnya, yaitu pada pra siklus minat siswa sebesar 61,12\% meningkat menjadi 66,729\% pada siklus I, dan meningkat pada siklus II menjadi 80,145\%. Selain itu, nilai rata-rata prestasi belajar Instalasi Motor Listri (IML) siswa mengalami peningkatan yaitu pada pra siklus ketuntasan sebesar 55.313 dengan persentase $31,25 \%$ (8 siswa), pada siklus I meningkat menjadi 70,21 dengan persentase ketuntasan 59,38\% (14 siswa), sedangkan pada siklus II meningkat menjadi 80,51 dengan persentase ketuntasan 81,25\% (19 siswa). Berdasarkan hasil penelitian diharapkan kepada para guru agar dapat menggunakan Model Pembelajaran Kooperatif Tipe Group Investigation yang merupakan salah satu model pembelajaran yang mampu meningkatkan minat dan hasil belajar Instalasi Motor Listri (IML) siswa.
\end{abstract}

Kata Kunci: minat belajar, hasil belajar, Group Investigation.

\section{ABSTRACT}

This study aims to increase the interest and learning achievement of Class XII TIPTL 2 SMK Negeri 3 Jambi City students in the 2018/2019 academic year by using the Group Investigation Type Cooperative Learning Model in the subject of Electrical Motor Installation (IML). This research method is CAR (Classroom Action Research). The research population used all XII grade students of SMK Negeri 3 Jambi City and the subject of this research was the XII grade TIPTL 2 students consisting of 23 students. The research was carried out in two cycles, assisted by two observers, collecting data using tests and observations. The results show improvement using this model. This is indicated by an increase in the percentage of the average results of the questionnaire sheet interest in learning Electrical Power Utilization Installation Engineering (TIPTL) each cycle, namely in the pre-cycle student interest by $61.12 \%$ increased to $66,729 \%$ in the first cycle, and increased in the second cycle. to be $80.145 \%$. In addition, the average value of student learning achievement in Electrical Motor Installation (IML) has increased, namely in the pre-cycle completeness of 55.313 with a percentage of $31.25 \%$ (8 students), in the first cycle it increased to 70.21 with a percentage of completeness $59.38 \%$ (14 students), while in the second cycle it increased to 80.51 with a completeness percentage of $81.25 \%$ (19 students). Based on the research results, it is expected that teachers can use the Group Investigation Type Cooperative Learning Model which is one of the learning models that can increase students' interest and learning outcomes for Electric Motor Installation (IML).

Keywords: interest in learning, learning outcomes, Group Investigation. 


\section{PENDAHULUAN}

Pendidikan merupakan salah satu pilar utama dalam menentukan perubahan sosial, Perubahan ke arah kemajuan dan kesejahteraan hidup yang berkualitas. Pendidikan bertanggung jawab atas terciptanya generasi bangsa yang paripuna. Sebagaimana tercantum dalam garis-garis besar haluan Negara yaitu terwujudnya masyarakat Indonesia yang damai, demokrasi, berkeadilan, berdaya saing, maju dan sejahtera, dalam wadah Negara kesatuan republik Indonesia yang didukung oleh manusia sehat, mandiri, beriman dan bertaqwa, berakhak mulia, cinta tanah air, berkesadaran hukum dan lingkungan, menguasai ilmu pengetahuan dan teknologi, memiliki etos kerja yang tinggi serta berdisiplin.

Pendidikan yang mampu mendukung pembangunan dimasa mendatang adalah pendidikan yang mampu mengembangkan potensi siswa, sehingga yang bersangkutan mampu menghadapi dan memecahkan problema kehidupan yang dihadapinya. Sekolah Menengah Kejuruan (SMK) sebagai satu diantara lembaga pendidikan menengah atas, memiliki tujuan untuk meningakat kecerdasan, pengetahuan, kepribadian, akhlak mulia, serta keterampilan untuk hidup mandiri dan mengikuti pendidikan lebih lanjut sesuai dengan kejuruannya. Dilihat dari pernyataan tersebut, maka sekolah menengah kejuruan (SMK) dituntut menghasilkan tenaga yang terampil dan bermutu serta cukup menguasai bidang digelutinya sehingga tantangan yang dihadapi peserta didik nantinya dapat teratasi (Nursalam, 2018).

Siswa SMK di Kota Jambi merupakan siswa yang memilih sekolah kejuruan karena terdapat berbagai pertimbangan. Antara lain adalah faktor ekonomi orang tua yang menghendaki setelah lulus sekolah bisa langsung bekerja. Orang tua siswa menghendaki anaknya mendapatkan ketrampilan dengan di sekolahkan di SMK Kota Jambi sebagai bekal hidupnya setelah lulus sekolah. Harapannya orang tua adalah bisa membantu meringankan ekonomi keluarga. Menurut informasi dari sekolah dan data yang ada bahwa prestasi siswa SMK di Kota Jambi selama ini dapat dikatakan masih rendah (berada di bawah rata-rata ketuntasan minimal yang harus dicapai siswa atau $<75$ ). Kondisi ini juga dapat dilihat dari jumlah tingkat ketidaklulusan yang masih tinggi di SMK jika dibandingkan dengan kelulusan pada SMU Kota Jambi.

Hasil observasi dari sekolah dan wawancara dengan guru di SMK Negeri 3 Kota Jambi, menunjukkan bahwa sebagian besar siswa kelas XII Teknik Instalasi Pemanfaatan Tenaga Listrik (TIPTL) 2 kurang semangat saat ada pembelajaran Instalasi Motor Listri (IML), mereka asyik ngobrol sendiri saat merasa jenuh dan hanya sebagian kecil siswa yang memperhatikan dan mencatat mata pelajaran yang diberikan oleh guru. Pengembangan pembelajaran yang diperlukan saat ini adalah pembelajaran yang menyenangkan dan nyaman dimana siswa selaku subjek belajar berani mencoba karena tidak takut salah. Sehingga dengan demikian minay siswa untuk belajar Instalasi Motor Listri (IML) lebih tinggi dan nantinya prestasi belajar akan maksimal. Pembelajaran di kelas yang masih berpusat pada guru membuat siswa hanya menerima materi pelajaran secara formatif, akibat dari pasifnya siswa dalam kelas menjadikan siswa jenuh sehingga kurang terminat dalam pembelajaran.

Untuk meningkatkan pemahaman konsep siswa, diperlukan model pembelajaran yang efektif. Dengan demikian yang perlu diperhatikan adalah keefektifan dalam memilih model pembelajaran, model pembelajaran yang dipilih harus sesuai dengan tujuan, jenis, dan sifat materi yang diajarkan. Kemampuan guru dalam memahami dan melaksanakan model tersebut sangat berpengaruh terhadap hasil yang dicapai. Rendahnya kemampuan pemahaman konsep karna proses pembelajaran lebih cenderung menggunakan model pembelajaran langsung yang terpusat pada guru dimana hal ini tentu saja menghambat perkembangan siswa dalam mengungkapkan ide-ide mereka. untuk itu guru harus mencari solusi dari permasalahan ini. Salah satu solusinya adalah cara pembelajaran yang menyenangkan seperti model pembelajaran Group Investigation (GI) (Khoiriah,2017).

Menurut Nadiya, dkk (2016) bahwa model pembelajaran Group Investigation mengarahkan aktivitas kelas yang berpusat pada siswa dan menyediakan peluang kepada guru untuk lebih banyak melakukan diagnose dan koreksi terhadap masalah-masalah yang dihadapi 
siswa. Menurut Sutama (dalam Wulandari, dkk, 2016) menyatakan bahwa model pembelajaran Group Investigation merupakan pembelajaran berbasis kelompok yang memberikan peluang kepada siswa untuk berdiskusi, berfikir kritis, dan dapat bertanggung jawab dalam pembelajaran tersebut. Harahap, dkk (2017) menyatakan model pembelajaran Group Investigation dapat menumbuhkan kehangatan hubungan antar siswa, kepercayaan, rasa hormat terhadap harkat dan martabat orang lain dan yang lebihpenting model pembelajaran Group Investigation dapat dipergunakan pada seluruhareal subyek yang mencakup semua anak pada segala tingkatan usia dan peristiwa sebagai model sosial inti untuk semua sekolah. Model pembelajaran Group Investigation merupakan model pembelajaran yang pertama kali dikembangkan oleh Thelan. Dalam perkembangannya model ini diperluas dan dipertajam oleh Sharan dari Universitas Tel Aviv (Pranata, 2016). Tujuan menggunakan model pembelajaran kooperatif tipe Group Investigation pada mata pelajaran IML untuk memudahkan siswa dalam belajar memahami materi pelajaran dan menjadikan proses pembelajaran tidak membosankan, sehingga pembelajaran tersebut akan menjadi pembelajaran yang menyenangkan dan menarik bagi siswa.

Kunci utama pembelajaran adalah minat. Pembelajaran akan terjadi jika siswa memiliki minat untuk belajar. Menurut Nurhasanah, dkk (2016) minat belajar besar pengaruhnya terhadap prestasi belajar, karena jika bahan pelajaran yang dipelajari tidak sesuai dengan minat siswa, maka siswa tidak akan belajar dengan baik-baik. Minat merupakan bentuk sikap dan ketertarikan atau sepenuhnya terlibat dengan suatu kegiatan karena menyadari pentingnya atau bernilainya kegiatan tersebut (Rahmayanti, 2016). Pada saat sekarang ini, Instalasi Motor Listrik (IML) bisa dikatakan merupakan salah satu mata pelajaran yang dianggap sulit oleh siswa. Karena itu minat siswa masih sangat kurang. Hal ini yang menyebabkan rendahnya prestasi siswa dalam pelajaran Teknik Instalasi Pemanfaatan Tenaga Listrik (TIPTL). Dengan adanya minat kegiatan belajar mengajar akan berjalan dengan baik dan seseorang akan lebih berkonsentrasi, tidak mudah bosan dan mudah untuk mengingat dengan apa yang dipelajari. Hal itu sesuai dengan yang dikatakan oleh S. Nasution dalam Kartika, dkk (2019) bahwa pelajaran akan berjalan lancar apabila ada minat. Siswa yang malas, tidak belajar, gagal karena tidak ada minat.

Adapun prestasi belajar merupakan target bagi siswa untuk mengetahui peningkatan hasil belajarnya. Firdianti (2018) menjelaskan bahwa prestasi belajar merupakan taraf keberhasilan sebuah proses belajar-mengajar (the teaching learning process) atau taraf keberhasilan sebuah program pembelajaran atau penyajian materi, dan kenaikan kelas. Menurut Hwang et.al (2013) prestasi adalah hasil yang telah dicapai dari apa yang sudah dikerjakan. sedangkan prestasi belajar menurut Monawati (2018) merupakan hasil yang dicapai oleh seseorang dalam usaha belajar sebagaimana yang dinyatakan dalam raport.

Dari pendapat para ahli dapat dikatakan bahwa prestasi belajar merupakan hasil belajar yang dicapai seseorang dalam usahanya melakukuan kegiatan belajar yang diukur melalui tes dan dinyatakan dalam nilai raport. Prestasi belajar yang dicapai seseorang merupakan hasil interaksi berbagai faktor yang mempengaruhi baik dalam diri (faktor internal) maupun luar diri (faktor eksternal). 1) Faktor internal merupakan faktor yang berasal dari dirinya sendiri meliputi kedisiplinan siswa, minat belajar, gaya belajar, minat belajar, keaktifan siswa, dan sebagainya. 2) Faktor eksternal yang mempengaruhi proses belajar meliputi lingkungan sosial, perhatian orang tua, fasilitas belajar dan sebagainya.

Berdasarkan uraian di atas, maka peneliti tertarik untuk melakukan suatau penelitian dengan judul "Upaya Peningkatan Minat dan Prestasi Belajar Siswa SMKN 3 Kota Jambi Melalui Model Pembelajaran Kooperatif Tipe Group Investigation”

\section{METODE PENELITIAN}

Penelitian ini merupakan Penelitian Tindakan Kelas (PTK) yang dilakukan di Kelas XII Teknik Instalasi Pemanfaatan Tenaga Listrik (TIPTL) 2 SMK Negeri 3 Kota Jambi tahun pelajaran 2018/2019 pada bulan Februari-April. Penelitian ini dilaksanakan minimal dalam dua 
siklus. Setiap siklus dilakukan dengan empat tahap yaitu: perencanaan (planing), tindakan (acting), pengamatan (observing), dan refleksi (reflecting). Subyek dalam penelitian ini adalah siswa Kelas XII TIPTL 2 SMK Negeri 3 Kota Jambi tahun pelajaran 2018/2019 yang berjumlah 23 siswa. Sedangkan objeknya adalah minat dan prestasi belajar IML dengan Penerapan Model Pembelajaran Kooperatif Tipe Group Investigation. Teknik pengumpulan data yang digunakan dalam penelitian ini adalah dengan angket, tes dan dokumentasi. Pada penelitian ini alat pengumpulan data digunakan untuk mengukur proses pembelajaran Model Pembelajaran Kooperatif Tipe Group Investigation.

Lembar angket digunakan untuk mengukur minat belajar siswa, tes prestasi belajar digunakan untuk mengukur prestasi belajar siswa, dan dokumentasi digunakan untuk memperoleh data nilai kemampuan awal siswa. Instrument penelitian yang digunakan peneliti untuk mengambil data yaitu lembar angket dan tes. Dalam penelitian ini menggunakan uji coba terpakai dengan kata lain uji coba digunakan sekaligus digunakan untuk uji coba instrumen. Uji coba instrumen tes dilakukan dengan menentukan validitas item, tingkat kesukaran, daya beda, dan realibilitas instrumen.

Rumus yang digunakan untuk mengukur validitas item dengan menggunakan rumus korelasi product moment. Hasil korelasi tersebut kemudian dikonsultasikan dengan tabel harga kritik $\mathrm{r}$ product moment pada taraf signifikan sebesar 5\%. Setelah konsultasi inilah dapat diketahui valid tidaknya instrumen yang digunakan. Apabila $r_{\text {hitung }} \geq r_{\text {tabel }}$ berarti instrumen tersebut dapat dikatakan valid. $\mathrm{r}_{\text {tabel }}$ untuk $\mathrm{n}=23$ dengan taraf signifikan 5\% adalah 0,349. Dari hasil perhitungan validitas item pada siklus I yang terdiri dari 20 item soal pilihan ganda, diperoleh 15 item yang valid, sedangkan item yang tidak valid ada 5 item, yaitu nomor 11, 12, 14, 16 dan 19. Pada siklus II dengan jumlah soal 20 item pilihan ganda diperoleh 17 item yang valid, sedangkan 2 item yang tidak valid yaitu item nomor 3, 10 dan 17.

Tingkat kesukaran digunakan untuk mengetahui sulit atau mudahnya soal tes yang diberikan. Rumus untuk mencari tingkat kesukaran adalah dengan membandingkan jumlah jawaban benar pada tiap item dengan jumlah siswa (Suharsimi Arikunto, 2009:208). Dalam penelitian ini, taraf kesukaran yang digunakan dari 0,30 sampai dengan $1,00(0,30 \leq \mathrm{TK} \leq 1,00)$. Dari butir soal yang digunakan pada penelitian ini mempunyai taraf kesukaran pada klasifikasi sedang dan mudah. Berdasarkan hasil perhitungan taraf kesukaran dari 20 butir soal pada siklus I terdapat 13 butir soal dengan klasifikasi sedang, sedangkan 7 butir soal dengan klasifikasi mudah. Pada siklus II terdapat 4 butir soal dengan klasifikasi sedang, sedangkan 16 butir soal dengan klasifikasi mudah.

Daya pembeda soal adalah kemampuan suatu soal untuk membedakan antara siswa yang pandai (berkemampuan tinggi) dengan siswa yang bodoh (berkemampuan rendah). Daya beda yang digunakan dalam penelitian ini adalah $0,2 \leq \mathrm{D}<0,70$ yaitu dengan klasifikasi cukup dan baik. Butir soal yang jelek tersebut tidakdapat membedakan kemampuan antara kelompok atas dan kelompok bawah, apabila butir soal yang jelek mempunyai daya beda yang negatif, sebaiknya butir soal tersebut tidak digunakan dalam tes selanjutnya. Dari perhitungan daya pembeda item pada soal tes siklus I terdapat 16 soal sesuai kriteria dan 4 butir soal yang tidak memenuhi syarat. Pada tes siklus II terdapat terdapat 17 soal sesuai persyaratan dan 3 soal yang tidak memenuhi syarat.

Untuk menghitung reabilitas tes, digunakan KR-20. Tes dikatakan reliabel apabila $\mathrm{r}_{\text {hitung }}$ $\geq \mathrm{r}_{\text {tabel. }}$. Berdasarkan perhitungan reliabilitas dari soal siklus I dilakukan terhadap 15 butir soal yang memenuhi syarat diperoleh nilai $r_{\text {hitung }}=0,762$ dan $r_{\text {tabel }}$ dengan jumlah item $(n)=15$, maka $r_{t(15)}=0,415$ (Robert L. Ebel, 1978). Hal ini berarti $r_{\text {hitung }} \geq r_{\text {tabel }}$ yaitu 0,762 > 0,415 maka tes dapat dinyatakan reliabel dengan klasifikasi tinggi. Berdasarkan perhitungan reliabilitas dari soal siklus II dilakukan terhadap 17 butir soal yang memenuhi syarat. Dari hasil perhitungan reliabilitas diperoleh nilai $r_{\text {hitung }}=0,815$ dan $r_{\text {tabel }}$ dengan $n=17$ adalah 0,449 . Ini berarti 0,815 $>0,449$ maka tes dapat dinyatakan reliabel dengan klasifikasi reliabilitas tinggi.

Teknik analisis data dalam penelitian ini yaitu diskriptif kualitatif untuk menganalisis proses pelaksanaan Model Pembelajaran Kooperatif Tipe Group Investigation dan peningkatan 
minat siswa serta interaksi belajar siswa yang diperoleh dari lembar angket. Sedangkan untuk menganalisis data berupa hasil tes belajar siswa menggunakan teknik diskriptif kuantitatif.

\section{HASIL DAN PEMBAHASAN}

Berdasarkan pengamatan sebelum tindakan kelas menggunakan lembar observasi minat yang dilakukan peneliti terhadap siswa diketahui minat siswa tergolong sedang. Dan dari beberapa indikator seperti siswa yang bertukar pendapat di depan dan siswa yang rajin bertanya masih tergolong rendah. Untuk itu perlu dilaksanakan pembelajaran yang dapat meningkatkan minat belajar Teknik Instalasi Pemanfaatan Tenaga Listrik (TIPTL) siswa.

Untuk mengetahui prestasi belajar dalam Teknik Instalasi Pemanfaatan Tenaga Listrik (TIPTL), maka peneliti menggunakan hasil nilai ulangan terakhir. Ulangan tersebut menghasilkan nilai rata-rata prestasi siswa sebesar 55,313 dengan jumlah siswa yang mencapai nilai KKM (75) adalah 8 siswa dan yang belum mencapai KKM sebanyak 12 siswa. Hal tersebut menandakan bahwa prestasi belajar Kelas XII TIPTL 2 SMK Negeri 3 Kota Jambi tahun pelajaran 2018/2019 masih rendah.

Pelaksanaan tindakan dalam penelitian ini dilaksanakan dalam dua siklus, dimana setiap siklusnya terdiri dari 3 kali pertemuan. Dengan menerapkan model pembelajaran tipe Group Investigation ini minat siswa mengalami peningkatan.

Berdasarkan hasil dari lembar angket siswa yang terdiri dari 4 indikator diperoleh hasil bahwa (1) orientasi keberhasilan dalam kegiatan belajar, pada prasiklus sebesar 68,5\% pada siklus I naik menjadi 69\%, dan pada siklus II adalah 79,75\%, (2) antisipasi kegagalan, pada prasiklus adalah 64\%, pada siklus I meningkat menjadi $64,125 \%$ dan pada siklus II meningkat menjadi 80,5\%, (3) inovasi dalam pembelajaran pada prasiklus adalah 58,5\%, pada siklus I mengalami peningkatan menjadi $69,166 \%$ dan pada siklus II meningkat menjadi $80,20 \%$, dan (4) tanggungjawab siswa dalam pembelajaran pada prasiklus adalah $58,3 \%$, pada siklus I menjadi $64,625 \%$ dan pada siklus II mengalami peningkatan menjadi $80,125 \%$.

Berdasarkan hasil tersebut dapat dilihat bahwa minat belajar siswa saat pembelajaran dengan menggunakan model pembelajaran Quick on the Draw mengalami peningkatan hal ini terlihat dari hasil rata-rata angket minat belajar Teknik Instalasi Pemanfaatan Tenaga Listrik (TIPTL) siswa. Hasil rata-rata angket pada pra siklus adalah $61,125 \%$, pada siklus I adalah $66,729 \%$ dan meningkat pada siklus II menjadi 80,145\%. Dengan kata lain minat belajar siswa Kelas XII TIPTL 2 SMK Negeri 3 Kota Jambi tahun pelajaran 2018/2019 meningkat.

Berdasarkan nilai awal prasiklus siswa yang diambil dari pembelajaran sebelumnya adalah sebesar 55,313 menunjukan prestasi siswa belum cukup baik. Sedangkan banyak siswa yang tuntas adalah 8 siswa sehingga persentase jumlah siswa yang belum memenuhi KKM sebesar $31,25 \%$ masih di bawah $75 \%$.

Pada siklus I prestasi belajar Teknik Instalasi Pemanfaatan Tenaga Listrik (TIPTL) siswa meningkat dengan nilai rata-rata 70,21 dan jumlah siswa yang tuntas sebanyak 14 siswa dengan persentase ketuntasan 59,38\% masih di bawah 75\%. Pada siklus II prestasi belajar siswa meningkat dengan nilai rata-rata 80,51 dan jumlah siswa yang tuntas sebanyak 19 siswa dengan persentase ketuntasan $80,125 \%$. Dengan kata lain pada siklus II semua aspek yang diteliti sudah memenuhi kriteria yang diharapkan baik minat maupun prestasi belajar siswa dan penelitian berhenti pada siklus II.

\section{KESIMPULAN}

Berdasarkan hasil penelitian yang telah diuraikan sebelumnya, dapat disimpulkan bahwa model pembelajaran tipe Group Investigation dapat meningkatkan minat belajar Teknik Instalasi Pemanfaatan Tenaga Listrik (TIPTL) siswa Kelas XII TIPTL 2 SMK Negeri 3 Kota Jambi tahun pelajaran 2018/2019. Peningkatan minat siswa dapat dilihat dari rata-rata presentase tiap indikator minat belajar siswa, sedangkan peningkatan prestasi belajar siswa dapat dilihat dari rata-rata hasil tes tiap siklus. 


\section{DAFTAR PUSTAKA}

Firdianti, A. (2018). Implementasi manajemen berbasis sekolah dalam meningkatkan prestasi belajar siswa. Gre Publishing.

Harahap, R. A., \& Derlina, D. (2017). Pembelajaran Kooperatif Tipe Group Investigation (GI) dengan Metode Know-Want-Learn (KWL): Dampak terhadap Hasil Belajar Fluida Dinamis. Jurnal Ilmiah Pendidikan Fisika Al-BiRuNi, 6(2), 149-158.

Hwang, G. J., Wu, P. H., Zhuang, Y. Y., \& Huang, Y. M. (2013). Effects of the inquiry-based mobile learning model on the cognitive load and learning achievement of students. Interactive learning environments, 21(4), 338-354.

Kartika, S., Husni, H., \& Millah, S. (2019). Pengaruh Kualitas Sarana Dan Prasarana Terhadap Minat Belajar Siswa Dalam Pembelajaran Pendidikan Agama Islam. Jurnal Penelitian Pendidikan Islam, [SL], 7(1), 113-126.

Khoiriah, H. N. L. (2017). Penerapan Model Pembelajaran Kooperatif Tipe Group Investigation (Gi) Untuk Meningkatkan Hasil Belajar Siswa Kelas X Tpm Pada Kompetensi Besaran \&Amp; Satuan Di Smk Dharma Bahari Surabaya (Doctoral dissertation, State University of Surabaya).

Monawati, M., \& Fauzi, F. (2018). Hubungan Kreativitas Mengajar Guru Dengan Prestasi Belajar Siswa. Jurnal Pesona Dasar, 6(2).

Nadiya, N., Rosdianto, H., \& Murdani, E. (2016). Penerapan Model Pembelajaran Group Investigation (gi) untuk Meningkatkan Keterampilan Berpikir Kritis Siswa pada Materi Gerak Lurus Kelas X. JIPF (Jurnal Ilmu Pendidikan Fisika), 1(2), 49-51.

Nurhasanah, S., \& Sobandi, A. (2016). Minat belajar sebagai determinan hasil belajar siswa. Jurnal Pendidikan Manajemen Perkantoran (JPManper), 1(1), 128-135.

Nursalam, R. (2018). PENGARUH MODEL TUTOR SEBAYA UNTUK MENINGKATKAN AKTIVITAS DAN HASIL BELAJAR PADA MATA PELAJARAN INSTALASI TENAGA LISTRIK KELAS XI SMK SWASTA TUNAS PELITA BINJAI TAHUN AJARAN 2017/2018 (Doctoral dissertation, UNIMED).

Pranata, E. (2016). Implementasi Model Pembelajaran Group Investigation (GI) Berbantuan Alat Peraga Untuk Meningkatkan Kemampuan Pemahaman Konsep Teknik Instalasi Tenaga Listrik (TITL). JPMI (Jurnal Pendidikan Teknik Instalasi Tenaga Listrik (TITL) Indonesia), 1(1), 34-38.

Rahmayanti, V. (2016). Pengaruh minat belajar siswa dan persepsi atas upaya guru dalam meminat belajar siswa terhadap prestasi belajar bahasa Indonesia siswa SMP di Depok. SAP (Susunan Artikel Pendidikan), 1(2).

Suharsimi Arikunto. 2009. Dasar-dasar Evaluasi Pendidikan.Jakarta: Bumi Aksara

Wulandari, P., Mujib, M., \& Putra, F. G. (2016). Pengaruh model pembelajaran investigasi kelompok berbantuan perangkat lunak MAPLE terhadap kemampuan pemecahan masalah matematis. Al-Jabar: Jurnal Pendidikan Teknik Instalasi Tenaga Listrik (TITL), 7(1), 101-106. 